\title{
Królewskie kaznodziejstwo okolicznościowe czasów Stanisława Augusta Poniatowskiego
}

Magdalena Ślusarska 


\section{MAGDALENA ŚLUSARSKA}

\section{Królewskie kaznodziejstwo okolicznościowe czasów Stanisława Augusta Poniatowskiego}

...szczęśliwość królestw od tego najbardziej zależy, żeby od Królów swoich znane byly..., uszczęśliwienie Królów i Monarchów od tego najbardziej zawislo, żeby od Poddanych swoich znanymi byli...

(S. Konarski, Kazanie... 1765)

Uroczystości związane ze świętami królewskimi obchodzono w całej Rzeczypospolitej z dużym rozmachem. Świętowano urodziny Stanisława Augusta ( 17 stycznia), jego imieniny ( 8 maja), rocznicę elekcji ( 7 września) i koronacji (25 listopada), a od dnia porwania i szczęśliwego ocalenia monarchy w 1771 r. także dzień 4 listopada, poświęcony Boskiej Opatrzności. Wśród tych świąt największą rangę miał, jak się wydaje, dzień 8 maja. Łączono bowiem w jedną trzy istotne uroczystości: kościelne święto patrona Królestwa Polskiego - biskupa Stanisława ze Szczepanowa, imieniny monarchy i "fest" ustanowionego w 1765 r. orderu św. Stanislawa, obok orderu Orła Białego najwyższego odznaczenia w Rzeczypospolitej. Nowy król zamierzał dekorować nim najbliższych i najbardziej zasłużonych dla swej polityki ludzi. Główne uroczystości odbywały się w tym dniu w warszawskim kościele Św. Krzyża na Krakowskim Przedmieściu. Odprawiano tam mszę pontyfikalną we wspomnianych trzech intencjach, podczas której wygłaszano dostosowane do potrzeb okoliczności kazanie. W świątyni księży misjonarzy Stanisław August odbył swe ekspiacyjne modły w przeddzień koronacji. Tutaj spowiadał się księdzu Piotrowi Śliwickiemu i przyjmował komunię. Jego poprzednicy odbywali $w$ tym dniu $w$ Krakowie pokutną pielgrzymkę z Wawelu do kościoła św. Michała na Skałce, gdzie w roku 1079 poniósł śmierć biskup Stanisław. Król-elekt Stanisław August, chcąc nawiązać do tej tradycji, kazał umieścić w kościele Św. Krzyża obraz św. Stanisława, przed którym wykonał wszystkie przewidziane obrządkiem czynności religijne ${ }^{1}$.

' A. Zgorzelska, Powrót króla, Warszawa 1991, s. 9. 


\section{Magdalena Ślusarska}

Poza stolicą także inne miejscowości składały hołd swojemu monarsze. $Z$ informacji prasowych wnioskować można, że nie tylko miasta trybunalskie, jak Lublin, Piotrków, Grodno i Wilno, ale także szereg miasteczek prowincjonalnych i prywatnych rezydencji brało udział $w$ organizowaniu królewskich uroczystości. Schemat obchodów był zwykle podobny. Tam, gdzie było to możliwe, dzień królewskich imienin witano stukrotnym wystrzałem z armat, uroczystą wotywą z kazaniem, niekiedy z procesjami duchowieństwa, cechów i zgromadzonej szlachty. Wieczorem następował bal z kolacją, wydawany przez dygnitarza świeckiego bądź duchownego, urozmaicany czasami występami teatralno-baletowymi. Zwykle iluminowano teren zabaw, a centralne miejsce zajmowała "cyfra" królewska - monogram SAR (Stanislaus Augustus Rex) ${ }^{2}$.

Wyjątkowego znaczenia nabierało wygłaszane $w$ tym dniu kazanie. Najwięcej informacji zachowało się o duchownych oracjach głoszonych w obecności samego króla, choć także na prowincji przywiązywano do nich dużą wagę. Część kazań warszawskich ukazała się następnie drukiem. Spotykamy się również z przypadkami publikacji podobnych mów wygłoszonych poza stolicą. Chodzi tu o te kazania, które nie miały charakteru trybunalskiego. Kazania trybunalskie, mówione w dniu imienin, elekcji i koronacji Stanisława Augusta należą do specyficznego typu oratorstwa kościelnego, które należy omówić oddzielnie.

Cykl kazań królewskich - które następnie ukazały się drukiem - otwierają oracje Piotra Śliwickiego i Sebastiana Lachowskiego, wygłoszone w roku 1765 w dniu ustanowienia orderu św. Stanisława. Lachowski - nadworny kaznodzieja Stanisława Augusta - przemawiał także w roku 1768. W 1772 wystąpił Marcin Krajewski, w 1775 -Wojciech Skarszewski, w 1776-Hugo Kołtątaj, w 1783 - Tadeusz Paszkowski, w 1784 - Benedykt Trzebiński, w 1785 - Florian Bujno, w 1787 - Franciszek Borowski, w 1789 - Jan Paweł Woronicz, w 1790 i 1791 ówczesny kaznodzieja królewski - Ignacy Witoszyński. W rocznicę uchwalenia Konstytucji 3 Maja kazał Adam Naruszewicz. O obchodach królewskich imienin w Warszawie i wyglaszanych wtedy duchownych oracjach szczegółowo informowała prasa.

Oprócz wspomnianych, znamy kazania wygłaszane w podobnych okolicznościach poza stolicą - przez Augustyna Lipińskiego w Plocku w 1775 r. i w Krakowie w 1789 r., Franciszka Synakiewicza w Pultusku w 1786 r. Edmunda Truskolawskiego $w$ Tulczynie w latach 1784-1786 oraz w Wilnie przez Wilhelma Kalińskiego w 1784 r. i Jana Nepomucena Kossakowskiego w okresie 1789-1793.

\footnotetext{
${ }^{2}$ Informacji na temat obchodów królewskich imienin dostarczają nam kolejne roczniki "Gazety Warszawskiej” i „Gazet Wileńskich”. Co roku w numerach następujących po tych świętach opisywano, jak przebiegały uroczystości w różnych miejscowościach Polski. Czasami drukowano specjalny dodatek oobchodach
} 
Kazania poświęcone jedynie tradycyjnym, kościelnym uroczystościom św. Stanisława znajdują się w większości homilijnych zbiorów kazań świętalnych różnych autorów. Mają one wtedy charakter uniwersalny. Bywało, że starano się je dostosować do potrzeb imienin królewskich, jak uczynit to Wawrzyniec Walkiewicz $w$ trzecim tomie swoich oracji, opublikowanym w $1786 \mathrm{r}^{3}$ Jednak nawet taki zabieg nie nadawał kazaniu owego wyjątkowego, okolicznościowego charakteru. Tworzono je raczej dla potrzeb duchowieństwa parafialnego i innego odbiorcy. Róźnie bowiem przemawiano wobec króla i intelektualnej oraz politycznej elity kraju, inaczej wobec społeczności Rzeczypospolitej prowincjonalnej.

Wspomniane mowy stanowią zbiór ponad dwudziestu kazań wygłoszonych w dniu królewskich imienin. Dołączyć do tego należy podobną liczbę oracji trybunalskich mówionych 8 maja lub 25 listopada i kilka z okazji innych królewskich rocznic. Otrzymamy ponad czterdzieści mów poświęconych szeroko rozumianemu problemowi monarchizmu w Rzeczypospolitej. Oddzielny, bogaty i niezwykle interesujący zestaw kazań poświęconych Konstytucji 3 Maja i jej rocznicy, w których także eksponowano osobę i rolę wladcy omówiony już został w oddzielnym artykule ${ }^{4}$.

Grupa duchownych, którzy wygłaszali w Warszawie kazania w dniu królewskich świąt wydaje się nie w pełni jednorodna. Byli wśród nich wybitni kaznodzieje, zajmujący się przede wszystkim oratorstwem politycznym, jak Jan Paweł Woronicz i lgnacy Witoszyński czy kaznodzieja trybunalski epoki saskiej Franciszek Borowski. Byli tacy, którzy nie wsławili się jako kaznodzieje, ale zajmowali się działalnością edukacyjną i państwową oraz pisarstwem politycznym i religijnym, jak Hugo Kołtątaj i Wojciech Skarszew ski. Ale byli i tacy, którzy opublikowali zaledwie to jedno właśnie wygłoszone w kościele św. Krzyża kazanie. Należeli do nich Tadeusz Paszkowski, Benedykt Trzebiński, Franciszek Bujno. Oprócz wspomnianego w gazetach ,powszechnego ukontetowania w słuchaniu i żądania druku" - nie wiadomo, co bezpośrednio decydowało o publikacji tej, a nie innej wypowiedzi. W grę mógł wchodzić prestiż kaznodziei oraz wykładnia polityczna jego oracji, chociaz wśród mów duchownych są także takie, w których przeważa motyw ewangeliczny. Spotykamy się także z przypadkami, gdy kaznodziejską wymowę danego mówcy sławi się jako ,gorliwą i prawdziwie

3 W. Walkiewicz, Kazania świętne i przygodne, t. 3. Warszawa 1786, dedykowane biskupowi poznańskiemu i warszawskiemu A. Okęckiemu. Jest to zbiór z „umieszczonym dziejopisem o biskupach poznańskich i pomiędzy innymi polożonym kazaniem o Sw. Stanislawie, przystosowanym do imienin Naj. K.P.M." ("Gazeta Warszawska" [dalej GW], 18.10.1786, $\mathrm{Nr} 83 \mathrm{~S}$ ).

${ }^{4} \mathrm{O}$ kazaniach dotyczących Konstytucji 3 Maja, zob. M. Slusarska, Konstytucja 3 Maja w kaznodziejstwie okolicznościowym lat 1791-1792, w: Rok monarchii konstytucyjnej. Piśmiennictwo polskie lat 1791-1792 wobec Konstytucji 3 Maja, praca zbiorowa pod red. T. Kostkiewiczowej. Warszawa 1992, s. 153-175. 
miodopłynną"5, a nie publikował on w ogóle swych wypowiedzi lub była to zaledwie jedna lub dwie pozycje. Dotyczy to Jakuba Dziewanowskiego, kapelana Korpusu Kadetów, człowieka wszechstronnie wykształconego, władającego kilkoma językami, cenzora pism religijnych, uznanego za głośnego kaznodzieję. Przemawiał on u księży misjonarzy w 1777 i 1786 roku, lecz nie drukował swych wystąpień ${ }^{6}$. Wśród mówców z kościoła św. Krzyża są także tacy, o których na podstawie dostępnych drukowanych źródeł informacyjno-encyklopedycznych i opracowań niewiele można powiedzieć. Ich nazwiska utrwaliła wspólczesna prasa tylko dlatego, że w tym właśnie szczególnym dniu wygłosili w obecności monarchy kaznodziejską orację. Byli to księża: Kuszel (1781), Sumiński (1782), Kwaśniewski $(1788)^{7}$. Nie znamy nawet ich imion.

O wyborze na mówcę nie decydowała na pewno przynależność zakonna. Byli wśród nich ex-jezuici i księża świeccy. Wszyscy nosili tytul kanonika, czyli duchownego, który z istoty swej funkcji przeznaczony jest do pomocy biskupowi w zarządzaniu diecezją oraz do sprawowania służby Bożej w sposób okazały i uroczysty. W większości byli to kanonicy warszawscy lub kijowscy, ale zdarzali się też płoccy, krakowscy i kamieniecki. Wydaje się, że bezpośredni związek z monarchą, tak jak w przypadku jego osobistego kaznodziei Ignacego Witoszyńskiego, nie był decydujący. Prawdopodobnie z formalnego punktu widzenia kaznodzieję wyznaczał biskup diecezji poznańskiej i warszawskiej. Niewykluczone są pewne sugestie ze strony Michała Poniatowskiego. Wśród mówców związani z nim byli: w 1780 roku Krzysztof Szembek, który nie opublikował swego kazania, a w 1783 roku kanonik płocki Tadeusz Paszkowski, wcześniej - jak podawała prasa - głoszący mowy w podobnych okolicznościach właśnie w Płocku ${ }^{8}$. Przemawiający w 1788 r. kanonik kamieniecki Kwaśniewski pozostawił po sobie mowę, jaką miał do prymasa Poniatowskiego w imieniu Trybunału Koronnego Piotrkowskiego w roku 1786. Wydaje się więc, że decydującym kryterium wyboru nie była wyjątkowa kaznodziejska pozycja mówcy, skoro część kazań nie została opublikowana.

${ }^{5} \mathrm{GW}, 10.05 .1786, \mathrm{Nr} 37 ; 23.09 .1786, \mathrm{Nr} 76$

${ }^{6} \mathrm{GW}, 10.05 .1777, \mathrm{Nr} 38 ; 10.05 .1786, \mathrm{Nr} 37$; L. Slowiński, Odważni mądrością. O reformatorach edukacji i nauki polskiej w dobie oświecenia, Poznań 1988, s. 117, PSB, t. 6, s. 169.

${ }^{7} \mathrm{GW}, 9.05 .1781, \mathrm{Nr} 37 ; 11.05 .1782, \mathrm{Nr} 38,10.05 .1788, \mathrm{Nr} 38$.

${ }^{8} \mathrm{GW}, 10.05 .1780, \mathrm{Nr} 38-\mathrm{w}$ roku 1780 Szembek nosil tytuł kanonika warszawskiego i koadiutora archidiakonii kolegiaty. Z czasem zostal koadiutorem biskupstwa płockiego, które objął w zarząd w roku 1785 po przejściu Poniatowskiego na urząd prymasa. Szembek kontynuowal rozpoczęte przez poprzednika prace na terenie diecezji. Paszkowski, kanonik płocki, glosil kazanie z okazji królewskich imienin w Plocku w roku 1781 (GW. 26.05.1781, nr 42).

9 Jest to jedynie hipoteza, że wygloszona przez Kwaśniewskiego mowa, która ukazala się drukiem w Warszawie 1786 roku mogła zwrócić uwagę prymasa na osobę kanonika i wtedy deputata kamienieckiego. Mowęodnotowuje Estreicher. 
Jeszcze trudniej zanalizować sytuację na prowincji. Generalnie mamy do czynienia ze zjawiskiem podobnym, jak w stolicy. Spotykamy się z nazwiskami słynnych oratorów kościelnych, jak Jan Nepomucen Kossakowski i Wilhelm Kaliński w Wilnie, ale także z mówcami lokalnymi, których miejscowa sława opierała się na przekazie ustnym lub być może rękopiśmiennym. Spotykamy wystąpienia duchownych, którzy zajmowali się przede wszystkim popularnym oratorstwem homilijnym, jak August Lipiński czy Franciszek Synakiewicz. Zdarza się, że w ośrodkach akademickich, jak Wilno i Kraków, kazania głosili nauczyciele uniwersyteccy, którzy także nie publikowali swych wystąpień.

Skupiając wokół siebie ludzi w sutannach, otwartych na pewne nowe prądy epoki oraz potrzeby kraju, Stanisław August starał się wykorzystywać katolicką ambonę także dla celów propagandowych ${ }^{10}$. Niejednokrotnie w różnych miejscach i sytuacjach padały z niej hasła zgodne z ogólnymi założeniami królewskiego programu odrodzenia Rzeczypospolitej. Wydaje się jednak, że zarówno mechanizm promocji mówców - co uwidacznia się najbardziej w przypadku kaznodzlejstwa trybunalskiego i umownie nazwanego królewskim czy dworskim - jak i samej treści propagandowej, nie był do końca dokładnie dopracowany i często zależał od indywidualnych predyspozycji mówców.

Imieninowe kazania królewskie inaugurują wspomniane już mowy wizytatora misjonarskiego i spowiednika władcy, Piotra Śliwickiego oraz jego kaznodziei Sebastiana Lachowskiego. Były to krótkie wystappienia, które obok sprawy nowego odznaczenia, poruszyly kwestię szczęścia królestw, monarchów i poddanych, uzależnioną od wzajemnego poznania się przez zainteresowane strony ${ }^{11}$. Ten element poznania się, zrozumiały $w$ pierwszym roku panowania Stanisława Augusta, będzie następnie rozwijany i poglębiany przez kaznodziejstwo w kwestię ufności, stałości, jednomyślności i zgody między narodem a suwerenem. Wzajemne pozytywne odniesienia między władcą a narodem wypływać powinny, zdaniem mówców, z zasad Ewangelii i praw spoleczności ludzkiej ${ }^{12}$.

10 A.J. Zakrzewski, Kształtowanie opinii publicznej w XVIII w. na przykładzie działalności kaznodziejskiej Michała F. Karpowicza (1774-1803), w: "Przegiąd Humanistyczny”, R. 22: 1978, nr 12 (159), s. 56-57; A.J. Zakrzewski, Idee Oświecenia w kazaniach polskich. (Studium literacko-socjologiczne). Częstochowa 1986, s. 89; L. Gruszczyński, Problematyka spoleczna i polityczna w kazaniach polskich w latach 1775-1795 (maszynopis pracy doktorskiej), Łódź 1980, s. 231.

11 P.H. Sliwicki, Kazanie w dzień S. Stanislawa Biskupa przy postanowieniu nowego Orderu w kościele warszawskim S. Krzyża roku 1765 przed Najjaśniejszym Królem Imcią miane przez... (B.m.), 1765, s. nlb. 4; S. Lachowski, Kazanie w dzień S. Stanislawa Biskupa przy postanowieniu nowego Orderu w kościele warszawskim S. Krzyża roku 1765 przed Królem J. Mością miane (B.m.), 1765.

${ }_{12}$ Wspomniane elementy występują w wielu nie tylko królewskich kazaniach czasów stanisławowskich. Eksponowalo je również oratorstwo trybunalskie i sejmowe. Motyw ten nasilał się w zależności od sytuacji politycznej. 
Podstawowym jednak motywem królewskiego kaznodziejstwa lat siedemdziesiątych jest wyraźnie i celowo eksponowany wątek porównawczy między św. Stanisławem a Stanisławem Augustem. W wytworzeniu się takiego właśnie ujęcia dopomógł bardzo fakt porwania króla przez konfederatów barskich 3 listopada 1771 r. i jego cudowne, jak następnie przedstawiano, ocalenie ${ }^{13}$. Fakt ten wywołał ogromne poruszenie w kraju i za granicą ${ }^{14}$. Przeciwko temu postępkowi opowiedział się Kościół. Andrzej Stanisław Kostka Młodziejowski, biskup poznański i warszawski, listem pasterskim z 9 listopada $1771 \mathrm{r}$. ostro potępił zamach jako pogwałcenie praw naturalnych, boskich i ludzkich. W diecezji kaznodzieje podczas specjalnych nabożeństw mieli wygłaszać przystosowane do tej materii kazania $^{15}$. W kolegiacie św. Jana odprawiono dziękczynną wotywę za ocelenie Najjaśniejszego Pana. Opublikowano kazania kapucyna ojca Bogumila Guzowskiego, który akt porwania przedstawił jako świętokradczy i bratobójczy, bardzo silnie eksponując przy tym motyw Opatrznościowy - wyjątkowej opieki Stwórcy nad Stanisławem Augustem ${ }^{16}$.

Zamach na króla umożliwił kaznodziejom już w roku następnym przeprowadzenie paraleli między obu Stanisławami. Najczęściej ograniczano się do podkreślenia podobieństw związanych z ich nauką, wyjazdami i wykorzystaniem pobytów w obcych krajach dla dobra własnej ojczyzny. Istotny był tu także motyw cierpienia, jakiego obaj zaznali ${ }^{17}$. Akcentowano również wątek obrony wiary i wypełniania powinności swojego urzędu. Stanisław

${ }^{13}$ "Monitor", nr 95 z 27 XI 1771 i nr 96 z 30 XI 1771, S. Konarski, Boskiej Opatrzności dowód oczywisty. Uwaga historyczna nad strasznym niebezpieczeństwem życia Najjaśniejszego Pana roku 1771, dnia 3 listopada (B.m.r.).

${ }^{14}$ Literatura barska (antologia) wyd. 2 zupełnie zmienione. Oprac. J. Maciejewski, Kraków 1976, s. LVII-LVIII.

${ }^{15}$ A.S.K. Młodziejowski, List pasterski... Warszawa 9.11.1771 r., s. nlb. 3-5, 13-15. [Z okoliczności porwania i ocalenia Stanisława Augusta.]

${ }^{16}$ O. Bogumil [Guzowski - kapucyn], Kazania podczas solennych wotyw odprawujących się na podziękowanie Bogu za wybawienie Nayjaś. Króla IMCl Stanislawa Augusta z niebezpieczeństwa śmierci uknowanej od zasadzonych zloczyńców, miane w kościele XX. kapucynów przez... w tymże kościele ordynaryjnego kaznodzieję. Warszawa 1772, s. 22, 5; o. Bogumił był kaznodzieja kolegiaty św. Jana $\mathrm{i} w$ niej wyglosił trzy kazania związane $z$ porwaniem i ocaleniem króla.

${ }^{17}$ Kazania świętalne poświęcone biskupowi Stanisławowi Szczepanowskiemu drukowano także we wcześniejszych okresach historycznych. Opublikowano ich niewiele i nie analizowano szczegółowo, jaki miały charakter. Byly to homilie, które wzorowały się na żywocie świętego pióra P. Skargi. gdyż na Skargę powolują się również kaznodzieje stanisławowscy. Wyjątkowość sytuacji po porwaniu i ocaleniu króla umożliwiła przeprowadzenie przesadnych czasami porównań. M. Krajewski w mowie z 1772 roku stwierdza nawet, że obaj ucierpieli $w$ ósmym roku sprawowania swoich urzędów, usiluje także połączyć dzień kanonizacji św. Stanisława (faktycznie bullę kanonizacyjną wydał papież Innocenty IV w Asyżu 17 września 1253) i elekcji Stanislawa Augusta - 7 września - z dniem Narodzenia Maryi Panny - 8 września, błędnie podając daty Szuka równieżpewnych podobieństw w datach rocznych. 
August przedstawiony w roli ofiary i nieomalże męczennika, porównywany do głównego patrona Korony, nabierał dzięki temu szczególnych cech sakralnych. Król odrzucony przez szlacheckie społeczeństwo, które domagato się jego detronizacji, powracał w aureoli wybrańca Boga, a mówcy widzieli w nim biblijnego Dawida ${ }^{18}$. Takie ujeccie nabierało mocy, gdy wszystkie nieszczęścia ostatnich lat, jakie dotknęły kraj - wojna domowa, obca agresja, gtód, morowe powietrze, a przede wszystkim utrata ziem w wyniku pierwszego rozbioru - zostały przedstawione jako kara boska za zepsute obyczaje, odejście od cnót ewangelicznych i religii objawionej. Taka argumentacja pozostawała w zgodzie z bardzo silnym w latach siedemdziesiątych nurtem walki z wszelkimi przejawami deizmu, ateizmu, libertynizmu i religii naturalnej. Na tym tle ocalenie Stanisława Augusta ,króla prawowiernego w religii, króla przykładnego w pobożności, króla więcej troskliwego o ocalenie wiary, aniżeli o wszystkie zaszczyty królowania" - to znak boskiego pokoju, wyjątkowego miłosierdzia i nadzieja na przyszłość ${ }^{19}$. Do motywów tych sięgał także Hugo Kołłątaj. W jednym znanym jego kazaniu z 1776 r. Kołłątaj widział Stanisława Augusta, króla dobrego i mądrego, nad którym specjalną opiekę roztoczyła Opatrzność, jako naśladowcę pasterskiej gorliwości biskupa Szczepanowskiego ${ }^{20}$.

Lata osiemdziesiąte przyniosły powolne odejście od przedstawionego wyżej schematu. Wątek monarchy jako obrońcy wiary stopniowo wypierany był przez motyw króla-obywatela. Dzięki takiemu ujęciu wykształciły się dwa wzorce oparte na powinnościach urzędu. W 1783 roku Tadeusz Paszkowski przedstawił św. Stanisława jako wzór chrześcijaństwa, a Stanisława Augusta jako wzór obywatelstwa, nazywając go wielkim królem²1.

M. Krajewski, Kazania na uroczystość Ś. Stanisława Biskupa i Męczennika, patrona Korony Polskiej w dzień imienin Najjaśniejszego Stanislawa Augusta... i na fest Orderu tegoż $S$. Stanisława..., Warszawa 1772, s. 32.

${ }^{18}$ A. Lipiński, Kazanie w dzień S. Stanislawa Biskupa i Męczennika w kościele katedralnym plockim podczas uroczystego nabożeństwa za szczęśliwe panowanie N. Stanisława Augusta... Warszawa 1775, s. 21.

${ }^{19}$ Ibid., s. 18, 20, 25; W. Skarszewski, Kazanie w dzień Ś. Stanislawa..., Warszawa 1775, s. 8. 28-29.

${ }^{20} \mathrm{H}$. Kolłątaj, Kazanie o gorliwości chrześcijańskiej, na dzień 8 maja pamiątkę męczeństwa S. Stanislawa biskupa krakowskiego, imieninami J.K. Mci i dorocznym obchodzeniem postanowienia Orderu kawalerów Św. Męczennika uroczysty w kościele Sw. Krzyża... powiedziane. Warszawa 1776, s. 28-29, GW, 8.05.1776, Nr 37.

${ }^{21}$ W latach 1777-1782 wyglaszane w kościele Sw. Krzyża kazania nie ukazaly się drukiem, chociaż prasa informowala o przebiegu uroczystości. T. Paszkowski, Kazanie na uroczystość Ś. Stanisława B.M. i Orderu Jego. Dnia 8 maja roku 1783. W kościele jixx Misjonarzów Warszawskich miane przez... Warszawa (b.r.), s. 34-35. Przedstawiając żywot Szczepanowskiego i cud wskrzeszenia Piotrowina, Paszkowski powoluje się na Żywoty świętych P. Skargi, cytuje także fragment kazania trybunalskiego A. Samplowskiego z Poznania z 1765 r. w dniu pierwszej koronacji Stanislawa Augusta. 
Biskupia czulość i gorliwość o dobro powierzonej sobie trzody z jednej strony i królewska troska o dobro powierzonego sobie królestwa z drugiej, nabierały podobnego znaczenia, równoważyły się. Nie chodziło tu więc o porównanie podobnych faktów z ich życia, lecz o wartość społecznie użytecznych postaw.

Wydaje się, że połączenie dwóch wątków - królewskiego i biskupiego - było charakterystyczne przede wszystkim dla kaznodziejstwa ośrodka warszawskiego i niektórych wystąpień prowincjonalnych na przestrzeni lat siedemdziesiątych i osiemdziesiątych.

Natomiast kaznodziejstwo trybunalskie, nawiązujące do królewskich rocznic nie eksponowało tak silnie tego problemu, skupiając się głównie na aktualnej, wszechstronnej działalności samego Stanisława Augusta.

Ciekawym przykładem są kazania nadwornego teologa Stanisława Szczęsnego Potockiego - Edmunda Truskolawskiego, wygłaszane 8 maja w latach 1784-1786 w Tulczynie. Dedykując je Potockiemu, musiał autor pamiętać o osobie monarchy. W swej obywatelskiej wykładni były one raczej zbliżone do kaznodziejstwa trybunalskiego, nie warszawskiego, zaspokajając równocześnie wolnościowo-republikańskie potrzeby wojewody ruskiego. Autor skonstruował trafne określenie "katolickiego obywatelstwa", czyli "cnotliwego obywatelstwa", które zasadzało się na religii objawionej i powszechnym uszczęśliwieniu całego społeczeństwa ${ }^{22}$. „Gazeta Warszawska" nazwała wystąpienie Truskolawskiego z 1784 roku ,,kazaniem panegirycznym"23.

Autorem kazania o istocie władzy jest wileński misjonarz Wilhelm Kaliński. Jego oracja $O$ zwierzchności z 8 maja 1784 r. przynosi rozważania nad hierarchiczną strukturą społeczeństwa i wzajemnymi zobowiązaniami różnych stanów w myśl popularnych w Rzeczypospolitej naturalnoprawnych koncepcji fizjokratycznych. W ujęciu Kalińskiego „zwierzchność" ma gwarantować obywatelom "bezpieczeństwo, wygodę i pomyślność". Jej istnienie związane jest z potrzebami społeczeństw. W kazaniu tym, różnym od znanych duchownych oracji gloszonych 8 maja, uderza troska zarówno - prawidłowe funkcjonowanie relacji między władcą a poddanymi, jak i w obrębie całego organizmu społecznego z uwzględnieniem położenia

${ }^{22}$ E. Truskolawski, Kazania na Święty Stanisław miane w Tulczynie. Warszawa 1786. Zbiór zawiera kazania z lat 1784-1786 oraz Mowę na poświęcenie choragwi regimentu imienia Potockich mianą w Tulczynie 1786 roku. Kazanie o "katolickim obywatelstwie" jest pierwszym z trzech - s. nlb. 3, 8, 11. Drugie porusza problem miłości ojczyzny oraz obowiązków chrześcijańskich stanu „cywilnego, prawodawczego i żolnierskiego", trzecie-jedności obywateli w "republikanckim" narodzie.

${ }^{23}$ Opis uroczystości w Tulczynie na karcie wklejonej do numeru 37 "Gazety Warszawskiej" z 8 maja 1784 r. 


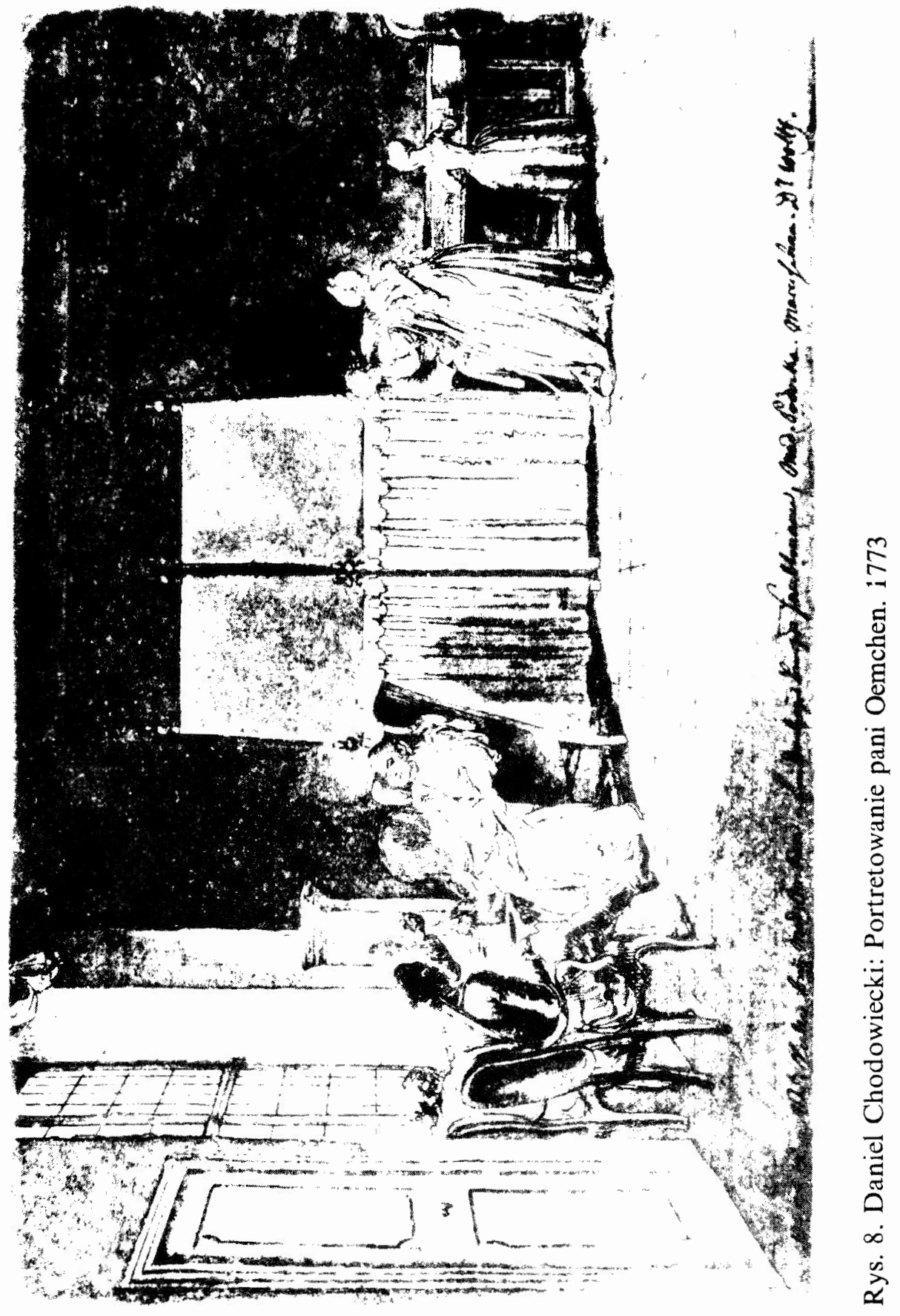


rolników wobec właścicieli ziemskich ${ }^{24}$. Zainteresowanie Kalińskiego sytuacją chłopów było jednąz charakterystycznych cech jego twórczości kościelnej. Wiązało się to również z inspirującą rolą biskupa Ignacego Józefa Massalskiego - wielkiego propagatora fizjokratyzmu, który stworzył w Wilnie silny ośrodek zwolenników tego kierunku.

Wzrost publicystycznego i politycznego napięcia u wrót Sejmu Czteroletniego był prawdopodobnie bezpośrednią przyczyną odejścia przez kaznodziejów od dotychczasowego schematu prezentacji problematyki królewskiej majowych oracjach duchownych. Kazanie Franciszka Borowskiego z 1787 roku, wygłoszone pod nieobecność monarchy w Warszawie (Stanisław August bawił wtedy w Kaniowie) nie przypominało wcześniejszych mów prezentowanych $w$ tym dniu. Nawiązywało raczej do wileńskiej oracji Kalińskiego z $1784 \mathrm{r}$. Stanowiło ono wykład $O$ wzajemnych obowiązkach panów i pospólstwa.

Na bazie nauki kościoła o przyczynach nierówności spolecznej, obowiążku miłosierdzia i posłuszeństwa snuł autor rozważania o istocie społeczeństw. Powstanie ich widział jako proces dobrowolnej rezygnacji z wolności partykularnej na korzyść powszechnej, co było popularnym w polskim Oświeceniu odbiciem poglądów J. Locka. Także poddaństwo chciał widzieć Borowski jako dobrowolne ofiarowanie się własnym panom, aby nie popaść $w$ niewolę u obcych ${ }^{25}$.

Kazania wygłoszone 8 maja w latach Sejmu Wielkiego miały charakter specyficzny. Prezentowane wobec króla i zjednoczonych stanów Rzeczypospolitej stawały się one oracjami sejmowymi, zachowując znamiona kościelnej mowy świętalnej. Obrady parlamentu znajdują w nich wyraźne odbicie. Zarówno Jan Paweł Woronicz w 1789 r., jak Ignacy Witoszyński w 1790 r. zwracali się z pochwałami do tych, którzy z dala od domów radzili nad losami ojczyzny. Królewski kaznodzieja wymieniał nawet z nazwiska wszystkich biorących udział w obradach senatorów, podkreślona została rola marszałka sejmowego, Stanisława Malachowskiego. Osoba króla schodziła na plan dalszy, chociaż pod jego adresem padały takie określenia, jak mądry, dobry, ojciec ojczyzny oraz ",monarcha prawdziwie prawowierny", "drużba prawowierny"26. Najistotniejszym jednak zagadnieniem, wokół którego ob-

${ }^{24}$ W. Kaliński, Kazanie w dzień Sgo Stanislawa w kościele Akademickim (O zwierzchności), Wilno 1784, w: tegoż: Kazania i mowy, Wilno 1805, t. 1, s. 254-257, 272-274.

${ }^{25} \mathrm{~F}$. Borowski, Kazanie na uroczystość orderową świętego Stanisława Biskupa Patrona Korony Polskiej .O wzajemnych obowiązkach panów i pospólstwa". Warszawa 1787. s. 20.

${ }^{26}$ J.P. Woronicz, Kazanie na dzień i uroczystość orderu ś. Stanisława biskupa i męczennika miane przed zgromadzeniem kawalerów tego orderu przez... dnia 8 maja 1789, Warszawa (b.r.), s. 4, 46; I. Witoszyński, Kazanie na uroczystość S. Stanisława, bpa krak. i męczennika. W czasie ciagu obrad Sejmowych, pod związkiem konfederacji rozpoczętych i rok już drugi agitujących sį̨ do Najjaśniejszych Rzplitej Stanów/przez.. Dnia 8 Maja R.P. 1790, (b.m.r.), s. 5, 37-40; 
racała się problematyka obwystąpień, była pozycja i rola Kościoła katolickiego w Polsce, zagrożonego w swym bycie materialnym na skutek ostrej krytyki publicystycznej, wymowy niektórych instrukcji poselskich i dyskusji oraz postanowień sejmu, a także wieści, docierających z rewolucyjnej Francji. Sprawy duchowieństwa, Kościoła i religii poruszali w swych pismach zarówno najwybitniejsi twórcy epoki - Stanisław Staszic i Hugo Kołłątaj, jak i autorzy pomniejsi, publikując nieraz swe krytyki anonimowo. W obronie pozycji Kościola w Polsce występował m.in. Wojciech Skarszewski, znany ze swych pism przeciwko Kodeksowi Zamoyskiego ${ }^{27}$. Widząc zagrożenie bytu duchowieństwa w Rzeczypospolitej, papiez Pius VI karcił swych podwładnych za opieszalość, nieumiejętność obrony własnych interesów i nawoływał do konsolidacji sił $^{28}$. Najwybitniejsi kaznodzieje epoki z Michałem Karpowiczem na czele wlączyli się do oratorskiej walki w obronie prerogatyw Kościoła. Również kazania trybunalskie z tego okresu powróciły niejako do tematyki ewangelicznej, glosząc niepodważalną rolę religii i Kościoła dla prawidłowego funkcjonowania społeczeństw. Duchowne oracje królewskie pozostawały więc w zgodzie z ogólnym, w danym momencie historycznym, nurtem pisarstwa religijnego, będącego odpowiedzią na faktyczne zagrożenie interesów Kościoła w Polsce.

Kazania Woronicza i Witoszyńskiego podkreślają niepodważalne znaczenie religii jako pierwszej zasady trwałości i szczęśliwości narodów oraz prawdziwej szlachetności człowieka. W sensie moralnym i politycznym religia jest gwarantem ladu i spokoju. W obu oracjach mamy do czynienia z silnymi akcentami skierowanymi przeciwko religii naturalnej, jak określa ją kaznodzieja królewski czy irreligii, jak pisze o niej kanonik kijowski. Jest to język znany z innych pism, broniących religii objawionej. Woronicz, nawią-

GW, 9.05.1789, Nr 37; GW, 12.05.1790, Nr 38 i 26.05.1790, Nr 42S - informacja o druku kazania. Tytul kazania Witoszyńskiego O źródlach prawdziwej szczęśliwości i trwałości narodów oraz jego wykladnia moralno-ewangeliczna, iż ,szczęśliwość narodów najdzielniej gruntuje bojaźń Boga, dowodzona trojakim względem: na religię, na obyczaj i na prawa. Trwałość zaś narodów najpewniej zaręcza pomoc Boga, blagana przez modlitwę i przez wzywanie przyczyny świętych pańskich" (GW. 12.05.1790, Nr 38) - wydaje się nawiązywać do litewskiego kaznodziejstwa trybunalskiego z okresu Sejmu Wielkiego. które dotykalo podobnej problematyki.

${ }^{27}$ Sprawy duchowieństwa, Kościola i religii w okresie Sejmu Wielkiego przedstawil W. Konopczyński w nie opublikowanej II części Polskich pisarzy politycznych XVIII w., poświęconej właśnie czasom Sejmu. - rozdz. XXII Sprawy duchowieństwa, Kościola i religii, s. 219-250 maszynopisu. Autor analizuje pisma zajmujące się powyższą kwestią. Rozpoczyna od oceny stanu duchowieństwa w Rzeczypospolitej, wspomina Księdza plebana J.J. Kossakowskiego i przechodzi do publicystyki sejmowej - od Staszica i Kollątaja poprzez Jacka Jezierskiego, Wojciecha Skarszewskiego, Jana Baudouina de Courtenaya i druki anonimowe. Przedstawia także postawę duchowieństwa w sprawie podatków i biskupstwa krakowskiego.

${ }^{28}$ Pius VI, Venerabilibus fratribus archi-episcopo et episcopis Regni Poloniae - Wielebnym braciom arcybiskupowi i biskupom Królestwa Polskiego, Rzym 5.09 .1789 (b.m.r.), s. nlb. 3-7. 
zując do sejmowego kazania Franciszka Salezego Jezierskiego z 1788 r., podkreśla wykorzystywanie fałszywej religii do celów politycznych: „bóstwo postawione na oltarzu postrachem dla gminu, a nauka o nim przybranym narzędziem dla interesu i polityki" - stwierdzał mówca ${ }^{29}$. W mniemaniu obu kaznodziejów istnieje uniwersaina, moralna oś świata, dzięki której prawidłowo funkcjonują społeczeństwa, a kto ją osłabia, jest wrogiem człowieka. Woronicz, dając teoretyczny wykład ksztaltowania się społeczeństw, a zatem dotykając problematyki, która nie była obca piśmiennictwu religijnemu epoki, podkreśla, iż siła dawnej Rzeczypospolitej leżała w przestrzeganiu zasad prawdziwej wiary, będących gwarantem dobrych praw i obyczajów. Witoszyński zastosował argumentację odwrotną, podkreślając słabość rozumu i natury, które bez nadprzyrodzonego światła Stwórcy mogą stać się siłą wrogą czlowiekowi. Obaj jednak dążyli do podobnego celu. Ich zadaniem było uzasadnienie niezbędności religii objawionej dla prawidłowego funkcjonowania spoleczeństwa, opartego na zasadzie hierarchiczności i wzajemnych obowiązków wszystkich członków, zajmujących konkretne miejsce w systemie wzajemnych relacji. Podkreślona została także rola duchowieństwa i praw zinstytucjonalizowanego Kościoła katolickiego w Polsce. Obaj sięgali do argumentów historycznych, idąc tu prawdopodobnie za Wojciechem Skarszewskim, a być może za Michałem Karpowiczem, którego kazania wygłoszone w Wilnie z okazji uroczystości św. św. Piotra i Pawła w 1788 i 1789 roku były historycznymi rozprawami na temat dziejów religii, Kościoła i urzędu kapłańskiego w Polsce. Woronicz i Witoszyński wspominali wolę przodków, którzy stan duchowny zabezpieczyli majątkowo i prawnie, nie szczędząc częstokroć własnej krwi. U Woronicza przebrzmiewały nawet elementy groźby, gdy niepokoił słuchaczy możliwością podważenia namiestniczego charakteru wszelkiej władzy, kiedy triumf odniosą hasła nowej nauki i filozofii, uznającej wyższość rozumu i wolnej woli nad Objawieniem. Zaś Witoszyński, choć traktował decyzję o zaborze dóbr biskupstwa krakowskiego (lipiec 1789) jako akt miłości ojczyzny i gorliwości "może trochę nadto zapędzonej", wszelkie inne plany wobec duchowieństwa uznawał za przeciwne równości stanów. Podobnie jak Woronicz używał on straszaka w postaci praw człowieka, które w rozpalonej namiętnościami sytuacji przekroczyć mogą granice wynikające $z$ ustalonego dotąd porządku społecznego, a ludzie staną się wtedy ,aż do zbytku i nieładu chciwymi wolności i równości"30. Niepokój duchownych wypływał $z$ dwóch źródeł - rodzimego i francuskiego. Przy tym pierwsze niosło chyba najbardziej zagrożenie natury bytowej i prestizowej, a drugie dotykało także sfery wiary, religii i społecznego porządku.

29 J.P. Woronicz, op. cit., s. 8.

${ }^{30}$ I. Witoszyński, op. cit., s. 28 
W Wilnie doby Sejmu Czteroletniego związane z obchodami imienin Stanisława Augusta patriotyczne kazania w akademickim kościele św. Jana głosił ksiądz Jan Nepomucen Kossakowski, autor pamiętnika, przyszły biskup wileński. Te bardzo ciekawe duchowne oracje w wieku XIX przysłonięte zostaly przez mocniej eksponowaną twórczość Karpowicza, Witoszyńskiego i Woronicza, stąd znajomość ich tematyki umknęła uwagi badaczy.

Cykl kościelnych wystąpień Kossakowskiego, nawiązujących do wewnętrznych problemów Rzeczypospolitej, otworzyło Kazanie o milości ojczyzny z 8 maja $1789 \mathrm{r}$. Był to bardzo popularny temat w kaznodziejstwie epoki. Powracali do niego prawie wszyscy duchowni, głoszący Słowo Boże w związku z otwieraniem obrad kolejnych sejmów. Sięgali do tej problematyki także kaznodzieje trybunalscy - warto przypomnieć choćby słynne litewskie mowy Michała Karpowicza z $1781 \mathrm{r}$. oraz lubelskie Benedykta Józefa Czajkowskiego z 1789 r. Temat ten zainspirował również Kossakowskiego. Podobnie jak część mówców, którzy odwoływali się do sejmowych kazań Piotra Skargi, także Kossakowski wykorzystywał słynny topos ojczyzny-matki i ojczyzny-okrętu z jego drugiego kazania sejmowego ${ }^{31}$. Nawiązał także do traktatu politycznego biskupa poznańskiego Wawrzyńca Goślickiego De optimo senatore libri duo z 1568 r. Goślicki był wielkim piewcą miłości ojczyzny, teoretykiem prawa i nauk politycznych, podkreślającym odpowiedzialność królów za swoje czyny ${ }^{32}$. Podobnie jak jego poprzednicy na ambonie. Kossakowski posłużył się znanymi już osobowymi wzorcami staropolskiego bohaterstwa i cnoty. Jego definicja ojczyzny pozostawała w zgodzie z myśleniem epoki na ten temat, obejmując obszar, ludność, dzieje, wspólnotę kulturową i religijną.

Kossakowski wyraźnie nawiązywał w swym kościelnym wystąpieniu do aktualnej problematyki politycznej, wspominając o toczących się obradach sejmowych. Podobnie jak $w$ innych kazaniach $z$ tego okresu dostrzec tu można ambiwalentne widzenie rzeczywistości politycznej. Czas sejmu postrzegany był przez kaznodzieję jako okres jedności i realizacji haseł miłości ojczyzny, moment powstawania z upadku pod kierownictwem króla i skonfederowanych stanów. $Z$ drugiej strony, narastająca krytyka duchowieństwa wywoływala przeciwdziałanie ze strony najwybitniejszych przedstawicieli kleru, czemu dawali wyraz w swych kaznodziejskich wystąpieniach. Podobnie postępował Kossakowski. Pochwalał on dobrowolne ofiary na wojsko, zarówno ze strony osób świeckich, jak i duchowieństwa, krytykował zaś

31 J.N. Kossakowski, Kazanie o milości ojczyzny w dzień Ś. Stanisława Biskupa krakowskiego pamiątkę jego męczeństwa i dorocznem obchodzeniem imienin J. Królew. Mości uroczysty... miane roku 1789, Wilno (po 12.06.1790), s. 15-17. Odpowiedni fragment u Skargi - P. Skarga, Kazania sejmowe, oprac. J. Tazbir, wyd. IV, uzupeł., Wroclaw 1984, s. 47-48.

32 PSB, t. VIII, s. 381; J.N. Kossakowski, op.j cit. s. d7 T18. 
tych wszystkich, którzy starali się zataić swoją sytuację majątkową. Występował także przeciwko sądom, które oczernialy duchowieństwo za jego zainteresowanie jedynie sprawami życia wiecznego i obarczającymi ten stan winą za nieprzygotowanie spoleczeństwa do umiejętności poświęcenia się dla dobra ojczyzny ziemskiej. Autor zdecydowanie umieszczał miłość ojczyzny wśród cnót naturalnych, nie odbierając jej jednak charakteru obywatelskiego ${ }^{33}$.

W rok później prałat katedry wileńskiej glosił kazanie poświęcone prawom narodowym. Pochwalał w nim dwuletnie prace sejmu nad poprawą rządu i aukcją wojska. Nawiązując do zagadnienia praw stanowionych, sięgal po dzieło Andrzeja Frycza Modrzewskiego O poprawie Rzeczypospolitej, przytaczając sąd autora 0 istocie praw i wynikających z nich powinności ${ }^{34}$. W przypisach do tego kazania umieścił Kossakowski przykłady polskich ustaw, które nie były respektowane lub wykorzystywano je dla interesów partykularnych. Cytował fragment siódmego kazania sejmowego Piotra Skargi $O$ prawach niesprawiedliwych abo o piątej chorobie Rzeczypospolitej, dotyczący egzekucji praw, podając go błędnie jako fragment kazania szóstego ${ }^{35}$. Kossakowski stał na stanowisku, że najdoskonalsze są te prawa, które zbliżają się do praw naturalnych, potwierdzonych boskim Objawieniem. Uważał także, że wszelkie zmiany w prawach Rzeczypospolitej powinny pozostać $w$ zgodzie $z$ duchem religii, eliminując równocześnie to wszystko, co ośmiesza Polskę w oczach oświeconej Europy. Kazanie to wyrażało aprobatę dla prawidłowo funkcjonującego prawa, które obywatelom winno gwarantować równość, wolność, bezpieczeństwo osób i majątków oraz tak istotne dla ludzi tej epoki „uszczęśliwienie”. Kossakowski wyrażał także nadzieję, że koniec XVIII wieku przyniesie oczekiwane dopuszczenie do praw tych wszystkich, którzy do tej pory byli ich pozbawien ${ }^{36}$. Dotyczyć to mogło zarówno stanu mieszczańskiego, jak wiejskiego, gdyż kaznodzieja nie precyzował swych myśli, ograniczając się do stwierdzenia o ludziach żyjących $z$ własnej pracy. Te pozaewangeliczne wywody Kossakowskiego nosiły na sobie wyraźne znamiona postępowej myśli polskiego Oświecenia. Kaznodzieja przestrzegał równocześnie przed nadmiernie rozbudowanym prawodawstwem, jako przykład zwięzłości ustawodawczej podając Danię. W przypadku prawa bowiem, obok strony teoretycznej, zdaniem mówcy, istotniejsza pozostaje rzeczywista możliwość egzekucji praw obowiązujących. Powracając do aktualnych wydarzeń politycznych konkludował, że gdyby decyzja o dowolnej ofierze na wojsko

33 J.N. Kossakowski, op. cit., s. 5-9.

34 J.N. Kossakowski, Kazanie o zachowaniu praw narodowych $w$ dzień uroczystości Ś. Stanislawa... miane roku 1790..., Wilno (po 12.06.1790), s. 50.

${ }^{35}$ Ibid., s. 58-59; P. Skarga, op. cit., s. 174.

${ }^{36}$ J.N. Kossakowski, Kazanie a zachowaniucpraw...|op. cit., s. 48-58. 
została konsekwentnie zrealizowana, jego zdaniem, nie zaistniałaby konieczność podejmowania dalszych aktów w tej sprawie, aktów, które uderzały, jak wiemy, także w Kościól ${ }^{37}$.

Jan Nepomucen Kossakowski głosił w Wilnie także kazania poświęcone uchwaleniu i pierwszej rocznicy Konstytucji 3 Maja. Omawiam je w oddzielnym artykule poświęconym Ustawie Rządowej, o czym wspominałam wyżej. Ostatnim jego wystąpieniem w dniu imienin królewskich była oracja z 8 maja 1793 r. Był on także autorem kazania inaugurującego obrady sejmu grodzieńskiego w czerwcu tego roku. Kazania sejmowe podobnie jak trybunalskie wymagają samodzielnego omówienia.

Majowe kazanie Jana Nepomucena Kossakowskiego nie poruszało bolesnego problemu upadku reform Sejmu Wielkiego i kolejnego rozbioru Rzeczypospolitej. Być może nawiązaniem do działalności konfederacji targowickiej, która szczególnie brutalnie poczynała sobie na Litwie, były słowa kaznodziei o tych, którzy wykorzystując hasła wolności, wprowadzają nierząd w miejsce ,najwyższej władzy rządowej". Mówca powracał do tak popularnego $\mathrm{w}$ piśmiennictwie Oświecenia, w tym także kaznodziejstwie tego okresu, stwierdzenia, że prawdziwą wolnością jest tylko wolność określona ramami prawa ${ }^{38}$. Apostrofa do Stanisława Augusta wyrażała pozytywny stosunek kaznodziei do monarchy, w którym upatrywać należało zwierzchność i winne jej było poszanowanie. To kazanie J.N. Kossakowskiego z 1793 roku było ostatnim znanym drukowanym wystąpieniem związanym z uroczystościami królewskimi. W dniach powstania kościuszkowskiego i wielkiej niepopularności monarchy, dzień jego imienin, szczególnie w Warszawie, starano się sprowadzić nieomalże do wydarzenia prywatnego, a z nieznanych powodów kapelana Szkoły Rycerskiej, Adama Królikiewicza, nie dopuszczono do wygłoszenia kazania w kościele św. Krzyża w dniu 8 maja 1794 r. $^{39}$ Być może władze insurekcyjne obawiały się prokrólewskiej wykładni duchownej oracji.

Okolicznościowe kaznodziejstwo królewskie czasów stanisławowskich posiadało znamiona wypowiedzi specyficznej wśród innego typu oracji kościelnych. Pod względem religijnym nawiązywało najczęściej do motywu Dobrego Pasterza z dziesiątego rozdziału Ewangelii według św. Jana.

${ }^{37}$ Ibid., s. 66.

38 J.N. Kossakowski, Kazanie o uszanowaniu zwierzchności w dzień dorocznej Stanisława świętego biskupa krakowskiego uroczystości... roku 1793. I za dozwoleniem zwierzchności do druku podane, Wilno (po 4.06.1793), s. 205-206.

${ }^{39}$ A. Woltanowski, Propaganda insurekcji kościuszkowskiej, Warszawa 1977, t. 1, s. 239 , 249 (maszynopis pracy doktorskiej). 
Łącząc fakt wygłoszenia kazania z monarszymi rocznicami, było równocześnie nawiązaniem do okolicznościowego, pochwalnego piśmiennictwa dworskiego, a zwłaszcza do poezji tego typu, niezwykle popularnej w tym okresie. Przykładem niech pozostanie twórczość Adama Naruszewicza, który w latach siedemdziesiątych komponowal liczne ody i pieśni na dzień urodzin, imienin, koronacji, ocalenia, a nawet powrotów do zdrowia i podróży królewskich ${ }^{40}$. Rocznice królewskie uświetniał swoimi wierszami Stanisław Trembecki, którego polityczne ody, propagujące politykę Stanisława Augusta i dotyczące ważnych aktualnych problemów, Mieczysław Klimowicz porównał do dzisiejszych artykułów wstępnych w prasie codziennej ${ }^{41}$. Choć poezja i twórczość kaznodziejska podlegały różnym wymogom formalnym, wydaje się, iż zestaw niektórych problemów i sposobów ich prezentacji był wspólny dla całego piśmiennictwa panegirycznego, poświęconego Stanisławowi Augustowi. Dotyczyło to kulturotwórczej roli monarchy oraz jego rozległych inicjatyw, służących podźwignięciu ojczyzny z upadku we wszystkich dziedzinach życia kraju - społeczno-ekonomicznej, edukacyjno-naukowej i politycznej. Przymioty i określenia, jakimi obdarzano Poniatowskiego - jako króla mądrego, dobrego, dobroczynnego, prawowiernego, syna i ojca ojczyzny, wreszcie króla-obywatela i króla-patriotę, a także częste porównywanie go do Henryka IV, zaś jego działalności do prac Kazimierza Wielkiego - było powszechne w piśmiennictwie, gloryfikującym jego osobę $i$ aprobującym monarszy program reformy; jak wykazują najnowsze badania historyków sztuki, zjawisko to wykraczało poza sferę piśmiennictwa i oratorstwa, obejmując także inne formy przekazu i komunikacji - malarstwo, rzeźbę, architekturę, medalierstwo. Było jednym z bardzo ważnych elementów świadomego budowania przez Stanisława Augusta obrazu idealnego władcy oświeceniowego ${ }^{42}$. Ambona zaś nadawała się doskonale do propagowania pewnych niesprzecznych $z$ religią haseł, co pozostawało przecież $w$ zgodzie $z$ tradycyjnymi, wielowiekowymi prokrólewskimi tendencjami panującymi w Kościele katolickim. Na ów hierarchiczno-sakralny stereotyp niezwykle misternie nałożono konkretną oświeceniową kliszę.

Do czasów Sejmu Wielkiego kaznodziejstwo dworskie, szczególnie ośrodka warszawskiego, zdaje się zachowywać pewną konwencjonalność wypowiedzi, ukształtowaną w pierwszym okresie rządów Stanisława Augu-

${ }^{40}$ A.S. Naruszewicz, Wybór poezji z dolączeniem kilku pism prozą oraz listów, wyd. popr. wedlug druków pierwotnych i opatrzone słowniczkiem archaizmów, Warszawa 1882.

${ }^{41}$ M. Klimowicz, Oświecenie, Warszawa 1980, s. 179; S. Trembecki, Pisma wszystkie, wyd. krytyczne oprac. J. Kott, t. 1. Warszawa 1953.

${ }^{42} \mathrm{O}$ tej niezwykle interesującej problematyce traktuje najnowsza praca J. Pokory, Obraz Najjaśniejszego Pana Stanislawa Augusta (1764-1770). Studium z ikonografii wladzy. Warszawa 1993. 
sta, a wynikającą z możliwości wykorzystania wątków, które prawdopodobnie dla wcześniej żyjących władców nie miały tak istotneo znaczenia.

Motywem przewodnim oratorstwa duchownego stał się wątek porównawczy między św. Stanisławem a Stanisławem Augustem, który odpowiednio interpretowany przekraczał granice wykładni ewangelicznej, a nabierał cech propagandowych. Podobne znaczenie miał silnie eksponowany wątek Opatrznościowy, na którego wymiar biblijny nakładała się współczesna rzeczywistość polityczna. Systematycznie następowało jednak wyraźne odejście od ujęcia pasyjnego, prezentującego króla jako męczennika, ku wizji króla-obywatela, należycie spełniającego powinności swego urzędu, podobnie jak niegdyś czynił to w innej, kościelnej płaszczyźnie biskup Szczepanowski. Na ową kościelną wykładnię podobieństw między obu Stanisławami zdecydowanie nakładał się oświeceniowy system wartości.

Kaznodziejstwo królewskie ośrodków trybunalskich, o czym zaledwie tu wspominam ze względu na obszerność tematu, choć nie rezygnowało z przypominania o namiestniczym charakterze władzy królewskiej, rzadko nawiązywało do motywu króla i biskupa. W większości tych oracji, szczególnie litewskich, duchowna akceptacja dla reformatorskiej działalności Stanisława Augusta nie miała charakteru panegirycznego, mimo zwyczajowych pochwalnych akapitów, lecz bliższa wydawała się prokrólewskiej agitacji publicystycznej. Na czoło rozważań kaznodziejów wysuwał się motyw spolecznej użyteczności monarszego urzędu, jego rola jednocząca i ponadpartyjna, a obraz króla-męczennika zastąpiony został przez portret pracującego dla dobra ojczyzny i jej obywateli króla-patrioty. Wątki obywatelskie umiejętnie splatano z motywami chrześcijańskimi, podkreślając religijną prawowierność monarchy i jedność obu postaw - duchowej i spolecznej.

Do kaznodziejstwa końca lat osiemdziesiątych gwałtownie wkroczyl konkretny czas historyczny, wypierając z niego misternie idealizowaną przeszłość z jej wielkimi bohaterami i moralno-obywatelskimi wzorcami. Znalazło to odzwierciedlenie we wszelkiego typu duchownym oratorstwie okolicznościowym, także królewskim. Podobnie rzecz się miała z całą literaturą tego okresu, w której zmiany wymuszone zostaly wielkim historyczno-politycznym przyspieszeniem ${ }^{43}$. Ogólną problematykę królewską zdominowały wydarzenia bieżące, istotne zarówno dla społeczeństwa Rzeczypospolitej, jak i dla jej Kościoła. Te ostatnie w określonych momentach zdawały się mieć nawet znaczenie ważniejsze dla przedstawicieli duchowieństwa niż całościowe problemy kraju. Kler polski nie zamknął się co prawda jedynie w kręgu partykularnych interesów swojego stanu - niemniej

${ }^{43}$ T. Kostkiewiczowa, Horyzonty wyobraźni. Warszawa 1984, s. 211. 
wyrażał zdecydowane zaniepokojenie narastającą wokół niego atmosferą niechęci i krytyki. Na kaznodziejstwo tego okresu zdawały się wywierać wpływ gorączkowe debaty przedsejmowe, niepokojące wieści, docierające z rewolucyjnej Francji, wzrost negatywnej oceny Kościoła i duchowieństwa w Polsce oraz szybko postępująca laicyzacja życia, wreszcie toczące się obrady i podejmowane $w$ trakcie ich trwania decyzje, dotyczące różnych sfer życia kraju. Stąd wyraźna zmiana tematyki królewskich kazań okolicznościowych. 